\title{
Apuntes sobre la escultura noucentista
}

\author{
CARlos D'ors FüHRER
}

\section{CONSIDERACIONES GENERALES DEL ARTE NOUCENTISTA}

El “Noucentisme» es un movimiento ideológico-estético que surge en Cataluña a principios de siglo como reacción frente al «Modernismo", al "Romanticismo" y, en general y por extensión, frente a todo el arte y el espiritu del "Fin-de-siglo". El "Noucentisme" cabalga cronológicamente de 1906 a 1929, con la "Exposición Universal de Barcelona", expresión del "Noucentisme» oficialista.

El “Noucentisme» se opone genéricamente a la mentalidad y al espíritu ochocentistas con una voluntad de rigor y un clasicismo que busca en el pasado renacentista y dieciochesco sus modelos ideales a imitar y teniendo como valores esenciales el orden, la claridad y la mesura. “Noucentisme" que se enfrenta al naturalismo, psicologismo y sentimentalismo, propios del siglo xix, critica el "Impresionismo" y el "Romanticismo", mostrando un deseo de jerarquia, con un gusto por la creación de espíritu mediterráneo, lúcida y, al mismo tiempo, lúdica, en contraposición al decadentismo finisecular.

El símbolo de esta renovación estético-filosófica del "Noucentisme» lo constituye la novela La Ben Plantada de Eugenio D'Ors. La figura helénica de Teresa, "La Ben Plantada" constituye la mejor versión plástico-literaria del "Noucentisme", una especie de simbolo en forma de estatua de lo que quería representar el "Noucentisme". Con su sentido del orden, de la serenidad y del clasicismo simboliza no sólo a Cataluña, sino todo el espiritu mediterráneo. El predominio de la idea-forma, es decir, del pensamiento figurativo es la esencia simbólica de la figura representada. El mensaje de esta obra es el ejercicio y aplicación de ese orden y ese clasicismo 
en la vida práctica. Estos van a tener para D'Ors el valor de canon, de norma de conducta, de moral y hasta de rito litúrgico. D'Ors pretende resolver el dilema pensamiento-acción: sentimiento-razón, y establecer como norma de vida, de estética y de inteligencia la forma y el control del pensamiento figurativo. Para el pensador catalán, filosofar era «pensar con los ojos" y la evidencia era videncia. Vida, estética y conducta estarian asi controladas por la inteligencia o seny, cualidad que libera de las tentaciones del enfermizo romanticismo, de la superficial improvisación y de las luchas internas de lo instintivo. Asi dice el autor: "Aconsejaron los últimos románticos: Haz tu propia vida como un poema. La Bien Plantada aconseja más pronto: Haz tu propia vida como la elegante demostración de un teorema matemático'".

"La Ben Plantada" constituye la más completa reacción frente a los epigonos del "Romanticismo", al afirmar su sentido de eternidad y universalidad y el valor del clasicismo latente en la sensibilidad y la cultura mediterráneas. Asi escribe Valbuena Prat refiriéndose a esta obra: «D'Ors hubiera querido ahogar las llamaradas de la arquitectura de Gaudi con los trazos sencillos del Partenón; limitar las estridencias amarillas del impresionismo de Rusiñol con la línea geométrica de Poussin; convertir ia sardana en sinfonia de Mozart»?

En resumen, el «Noucentisme" artístico fue una reacción en las artes frente al carácter medievalizante imperante entonces en el arte de Cataluña, que estaba saturado de elementos neogóticos procedentes del Norte de Europa. Éstos van a ser sustituidos por una tradición greco-latina del Mediterráneo clásico que oponia la forma y la concreción estructural a los paisajes brumosos del "Romanticismo" y a la fusión de las formas en la luz del "Impresionismo". Frente a las nieblas y negruras del irracionalismo nórdico del "Modernisme", el "Noucentisme" reivindica el seny (sentido), la razón, la claridad y la luz del Mediterráneo mar, el paisaje dominable y domesticable, vestido de viña y olivar, bajo un ritmo de arcos. Algunos autores interpretan esta mitologia mediterránea dulce, tierna, suave, tranquila, ordenada y ordenadora como una reacción de los pueblos meridionales frente a la agresividad nórdica y el nacionalismo de los septentrionales.

El “Noucentisme» proponía, en fin, la armonia y el canon mediterráneos frente a la expresividad germanizante fantasiosa e inquieta del "Modernisme". Colocaba en segundo término las formas espontáneas de la expresión y de lo instintivo, asi como el uso y abuso de lo folklórico que

E. D'Ors: La Bien Plantada. Barcelona. Ed. Planeta, 1982, pág. 157.

Ibidem. Prólogo de Carlos D'Ors, pág. 14. 
predominaban en la tradición ochocentista, para plantear una posición no sometida a la Naturaleza, sino de base intelectualista, una estética del arbitrarismo", artificial, creativa poiética, de carácter intemporal o sobretemporal, esto es, la obra de arte sub specie aeternitatis y con unos modos culturales de acuerdo con las más exigentes corrientes europeas.

Para el "Noucentisme", el arte no debe nunca convertirse en imitatio, porque eso equivaldría a subvertir la jerarquia y primado del espíritu. "No le basta al artista, al poeta que tiene sed, beber el agua en los manantiales de la Naturaleza como fuente de vida suprema, sino que ha de ser él quien deje caer sobre ia Naturaleza el torrente espumoso de su espíritu".

Finalmente diremos que el "Noucentisme" artístico, a pesar de manifestarse en todas las artes e incluso en las llamadas "artes menores", fue, en espíritu, un arte fundamentalmente "escultórico", un "arte de la forma". Si hay algún arte en que toda la teoria del clasicismo y del mediterranismo noucentistas logre una aproximada concreción es en el arte de la escultura, o mejor dicho, en el de la estatuaria. El "Noucentisme" es identificable sobre todo en la escultura y "La Ben Plantada" es, desde luego, antes que nada una estatua. D'Ors tenia proyectado que la escultura que representase a La Ben Plantada la realizase el gran escultor rosellonés Arístides Maillol, proyecto que, finalmente, no se llevó a cabo. Además, el “Noucentisme" reivindica el siguiente lema: "Las ideas que no se pueden esculpir no sor. más que vulgares nociones".

Asi pues, el "Noucentisme" denuncia el "provincianismo" en el arte catalán, demasiado atento a las influencias extranjeras, tanto nórdicas como parisinas, orientándose primordialmente hacia un claro "mediterranismo" de tradición greco-latina.

\section{UN CLASICISMO MEDITERRANEO}

Es evidente que uno de los aspectos esenciales de la escultura noucentista y, en general, de todo el arte noucentista es su "clasicismo mediterráneo o mediterranista". Se ha repetido insistentemente que el "Noucentisme" supone una vuelta a la tradición clásica y, en ese sentido, un tipo de "nuevo clasicismo". Desde luego, parece indudable que los noucentistas, reaccionando contra el germanismo, el anglicismo y el espiritu nórdico en general, propusieron una orientación hacia la Roma y la Grecia antiguas. Este "clasicismo" propuesto por los noucentistas gozaba además, según ellos mismos, de una larga tradición que, partiendo de la cultura greco-latina, empapa la civilización occidental, si bien con algunas interrupciones denominadas genéricamente «romanticismos». 
Por otra parte, este "clasicismo" cantado y ensalzado por los noucentistas encontraria un gran refrendo en el descubrimiento o hallazgo en las excavaciones emprendidas en la colonia griega de Ampurias de un «Asclepio" o "Esculapio" y de una "Cabeza de Venus, Afrodita, o de Diana» que inmediatamente cobraron valor simbólico y fueron utilizados por los noucentistas como símbolo de aquella Cataluña entroncada con la Antigüedad que ellos reivindicaban, creando asi el mito de la "Catalunya griega".

Para los noucentistas, ser "clásico" no sólo era una forma de expresión artística y toda una estética, sino también un deber y una obligación, algo constitutivo del catalán y de lo catalán. Por eso, el clasicismo cultivado y desarrollado contribuirá a hacer de Cataluña un pueblo grande, auténtico, esencial y actual.

No todos los pensadores noucentistas tienen idéntico concepto del "Clasicismo", aunque sí análogo. Para D'Ors, "clasicismo" en un sentido estético es reposo, estatismo, peso, enraizamiento; para Francesc Pujols equivale a "armonia", como cualidad constitutiva de la belleza; Torres García ve el "clasicismo" como un valor perdurable, eterno, algo connatural con el espiritu mediterráneo y catalán, fuera del tiempo, universal, cuyo contenido engloba serenidad, alegría, luz, sentido afinado de proporción, plasticidad y pureza ideal desligada de todo realismo.

Hemos visto que ese clasicismo es algo propio de lo mediterráneo, es decir, es un "clasicismo mediterráneo". Descubrir el Mediterráneo como cultura, como forma de vida y de convivencia de los hombres, recoger así, la herencia de la polis griega, subyacente en la cultura y en la tradición de Cataluña es otra obsesión de los noucentistas. Esta "constante mediterránea" permitirá llenar las lagunas del pasado mirando los ejemplos de Grecia e Italia, y buscando su fuente en un substrato popular sometido a ordenación, como los clasicismos de los momentos de grandeza de Atenas, de Roma, de Florencia o de Versalles.

El "Noucentisme" indentificará el mar de Grecia con el mar de Cataluña. Asi, la manera de pensar y de expresarse plásticamente de los catalanes estará condicionada por la acción determinante de un paisaje $y$, por ello, los hombres del Mediterráneo experimentarán hoy la misma influencia de tipo geográfico que los de la Antigüedad clásica. Por ello, el deber de ios artistas catalanes y de los que orientaban espiritualmente a Cataluña era "descubrir lo que había de mediterráneo en los catalanes y plasmarlo y ponerlo de relieve».

Existe una clara vinculación o relación entre «mediterranismo» y «clasicismo». El "mediterranismo" actúa sobre el "clasicismo" por dos lados, que son sus dos caras: la geográfica y la racial. El "clasicismo» es asi, tanto el producto de su área geográfica determinada (los paises mediterrá- 
neos), porque es en el Mediterráneo donde se ha desarrollado, como el resultado de la actuación "normal» de una raza (la de los hombres nacidos en sus orillas), porque el "clasicismo" es una obligación que impone el hecho de ser mediterráneos. El "mediterranismo" es totalizador: empapa y cubre la forma de vida y sensibilidad del catalán, y es, al fin y a la postre, la forma geográfica, racial y social del "clasicismo". Este "clasicismo mediterráneo" está magistralmente plasmado en obras como La Ben Plantada de D'Ors o La deesa de Clará. El gran poeta Joan Maragall canta las dulces formas escultóricas de Clará escribiendo que "son hermanas de aquellas inmortales hijas de nuestro mar al otro lado" y que "se alzan a la luz con aquella misma serenidad del genio antiguo" ${ }^{3}$.

El "Noucentisme" supone a manera de un "nuevo clasicismo" que busca sus raices muy lejos en el mundo greco-latino, si bien se tiñe también de reminiscencias renacentistas y dieciochescas. Este "clasicismo" presenta la adjetivación de "mediterráneo o mediterranista". Si el mar es símbolo de inmensidad e infinitud, el mar Mediterráneo supone una cierta forma de "limitación», O si se quiere, una especie de «mar-lago". Este "poner límites a las cosas" y "a la Naturaleza" es una de las características esenciales del "Noucentisme". Cataluña acusa precisamente, tanto en su paisaje de interior como en sus costas, este sentido de limite y de orden que tan bien supieron traducir los artistas noucentistas.

\section{EL PREDOMINIO DE LA FORMA}

Una de las características primordiales de la escultura noucentista es el "predominio de la forma». El "Noucentisme" adopta la búsqueda de la "forma" para llegar a una claridad clásica de carácter mediterráneo. La "forma" es el elemento esencial de la belleza plástica, hasta el punto de confundirla con el todo. La "forma" es la que encierra la esencia de los objetos. La "forma" es indispensable, inherente, integral, inseparable de las impresiones que nos producen las obras de arte. Es la que interviene como soberana de todo poder en las sensaciones que percibimos por la vista hasta destruir o armonizar las de color o de las luces. Ella es el medio productivo de las emociones artísticas en los hombres.

\footnotetext{
${ }^{3}$ Firmado J. Maragall y fechado Barcelona, 2 de junio, 1911. (Piedra inscrita en memoria de CLARÁ a la entrada del "Museo CLARÁ. de Barcelona).
} 
D'Ors insiste en el valor de la "forma" al escribir: "La forma decide. El exterior decide. La actitud decide. Cualquier gabán tratado como impermeable, se vuelve impermeable»"

Precisamente es en las obras escultóricas en donde se remonta más cerca de la sublimidad el valor de la forma. ¿Quién fue la mujer de tan espléndida hermosura que inspiró aquella estatua de Venus hallada en Milos? ¿Y el escultor de tan grandes condiciones y clara percepción que la ejecutó?

Resumiendo: el pensamiento noucentista es plástico, figurativo, búsqueda de la forma, arte del dibujo y de la estructura. Para los noucentistas, la filosofia es saber mirar y saber dar forma a lo visto, configurarlo, conformarlo: las ideas-formas. Las ideas-formas son ideas dotadas de figura y, por tanto, intuibles, intelectualmente visibles. La "forma" es la misma realidad del mundo y de la persona. En ella se alberga la idea y su belleza. Para el "Noucentisme", la forma es el elemento esencial de la belleza plástica porque encierra la esencia de los objetos. Asi, lo más espiritual de una cosa es su puro contorno. Si la forma es el espíritu, la repetición de la forma dará el espiritu. La “forma» será, pues, lo espiritual del arte.

A la recuperación de los valores volumétricos y de la forma contribuye decisivamente la publicación del libro de Adolf Von Hildebrand (18471921) El problema de la Forma, que fue muy leido en toda Europa y ganó la causa del formalismo frente al pictoricismo romántico escultórico.

\section{EL DESNUDO FEMENINO COMO TEMA}

Una de las notas más significativas de las escultura noucentista es el predominio del desnudo femenino como tema. La práctica totalidad de los grandes escultores noucentistas, desde Maillol a Rebull, desde Clará a Viladomat, cultivaron básicamente el modelado sincero y directo del cuerpo desnudo de la mujer mediterránea casi como única fuente de inspiración. Tal vez este tema único se deba precisamente a ese "predominio de la Forma" y a ese "clasicismo" mediterráneo, sereno e idealizado, de los que hemos insistido, y que, posiblemente, puedan reflejarse de modo más aproximado y certero en el desnudo femenino, al modo de las "Venus" de la Grecia clásica.

\footnotetext{
${ }^{4}$ E. D'ORs: Gnómica, Madrid. Col. Euro, 1941, pág. 11.
} 


\section{PRINCIPALES REPRESENTANTES DE LA ESCULTURA NOUCENTISTA}

Como ya hemos afirmado, el "Noucentisme" es estilísticamente identificable con la escultura, y "La Ben Plantada» es fundamentalmente una estatua. Así, según Marfany "sólo podemos hablar de pintura o literatura noucentistas si no definimos el "Noucentisme" con criterios estrictamente estilísticos, sino con otros menos específicos: ideológicos e históricos. Si nuestra definición es estilistica, entonces sólo podemos aplicar el término de una manera genérica en la escultura y sólo de una manera muy parcial en la pintura y en la literatura"

En la escultura catalana de los años 1910-1930 dominará, de manera proponderante, el mediterranismo que propugnaron los noucentistas. Aristides Maillol, Josep Clará, Enric Casanovas, Esteve Monegal van a realizar su obra dentro de los cánones dorsianos, matizados por el paso del tiempo. Otros, como Manolo Hugué o Pau Gargallo les seguirán en un momento determinado o en unas obras concretas. Después de la guerra, Joan Rebull prolongará la tendencia de manera más radical; otros escultores como Federic Marés y Enric Monjó partirán de un rígido clasicismo que les llevará a un cierto monumentalismo; y, por fin, Josep Viladomat o Apelles Fenosa llevarán su clasicismo mediterráneo por derroteros más realistas, el primero, y más fantasiosos, el segundo.

En la conformación de la escultura catalana más representativa del "Noucentisme" tiene una gran importancia la Cataluña francesa como "tierra de nadie" o, por mejor decir, como "tierra de todos". La escultura noucentista en la Cataluña francesa está personificada por el gran escultor de Banyuls, Aristides Maillol.

Atraído en principio por el potente foco parisiense y por la fuerte personalidad de Auguste Rodin, Arístides Maillol se halló consigo mismo aproximadamente en el momento del cambio de siglo. En el arte galo dominaban por aquel entonces dos claras tendencias: la constructiva sobriedad del provenzal Cézanne y el cálido hedonismo lumínico del último Renoir, definitivamente establecido en la Provenza. Por ambos artistas, tránsfugas del «impresionismo»e hitos sobresalientes de una amplia visión mediterránea, se siente Maillol, diriamos que, por la fuerza de sus orígenes, irrevocablemente atraido. Maillol iba a ser el gran escultor de este mediterranismo profundo. Cuando realizó, en 1900, una mujer sentada, robusta, reposada y perfecta tituló significativamente a aquel desnudo "Mediterránea". Con ella había esculpido no sólo la que tal vez sea su

`J. LL. Marfany: "Modernisme i Noucentisme amb algunes consideracions sobre el concepte de moviment cultural», Barcelona. Rev. Els Marges, $n^{\circ} 26,1982$, págs. $31 \vee 32$. 
mejor obra, sino indiscutiblemente el programa estético de la escultura catalana noucentista. Maillol con "Mediterránea" y las numerosas obras que la siguieron impuso internacionalmente un nuevo clasicismo: un clasicismo evidentemente enamorado de la escultura griega, aunque, eso si, declaradamente antipraxiteliano. Maillol llegó al clasicismo partiendo básicamente del modelaje sincero y directo de la mujer catalana, de la mujer mediterránea, que durante toda su larga vida fue casi única fuente de inspiración. Si como decia Xenius, la estatuaria noucentista habia de ser hecha para "alzar su blancura triunfante bajo nuestro sol, cerca del mar azul en las ágoras o en los jardines" ${ }^{6}$, las obras de Maillol satisfacen plenamente esta condición. Maillol personifica, como ningún otro, la alternativa serena, clásica y meridional del "Noucentisme" frente al impresionismo nervioso y nórdico de Rodin y al modernismo de raíz germánica.

Los principales escultores noucentistas de la Cataluña cispirenaica llegaron a un clasicismo similar al de Maillol después de pasar por una casi inevitable etapa de formación nórdica o modernista.

Josep Clará triunfa con sus desnudos femeninos, cuyo paradigma es su "Deesa" de 1909. Las sólidas diosas de Clará, de un clasicismo fiel a la tradición griega, son la versión plástica y tangible de la mujer arquetipica descrita por D'Ors como "La Ben Plantada". No es de extrañar por eso que en las propias páginas de la novela aparezca citada la escultura de Clará como arquetipo de la nueva catalanidad. Las figuras que salen de sus manos diríamos que se abandonan satisfechas a su destino puramente plástico. Si se mueven, es por un instinto muscular, no por pleitear a favor de preocupación interna alguna, sino porque sienten la felicidad de vivir la belleza de aquel momento que el artista perpetúa con emoción. Todo es psicológicamente desinteresado y la emoción está confiada a la eficacia estrictamente plástica de la figura. Como Maillol, Clará considera el desnudo femenino como el tema omnipotente que le permite conquistar las armonías de volumen y superficie más perfectas. Todo el esfuerzo creador de Clará se aplicó a plasmar una figura: la figura femenina que encarnase el ideal de belleza que vivió en el artista. Toda la producción de Clará no tiene otro norte que éste: crear un tipo que compendiase una forma de belleza subjetiva que trascendiese a una objetividad permanente. Los admirables desnudos de diosa de Clará "si Barcelona fuera ya una verdadera metrópolis, alzarian su blancura triunfante bajo el sol nuestro, a la orilla del mar azul, en las ágoras o en los jardines. (...) Los catalanes que no hayan visto aquellas estatuas, no saben hasta qué punto son griegas; ni saben tampoco hasta qué punto el griego es cosa moderna, sangre

"E. D’Ors: “Els Clará, noucentistes”. Febrero de 1909, dentro del libro Glosari 1906-1910. Obra Catalana Completa. Barcelona. Ed. Selecta, 1950, pág. 949. 
nuestra, carne nuestra, pasión nuestra, dolor nuestro, negocio nuestro, y amor, y anhelo..." ${ }^{7}$.

Enric Casanovas llegó, como Clará, al “mediterranismo" en los años finales de la primera década de nuestro siglo y como aquél fue siempre fiel a su arquetipo escultórico propio, concretado en desnudos y cabezas de muchacha, creando un arquetipo femenino arcaizante y muy personal. Cuando en Londres, en 1912, contempla los frisos del Partenón se siente transformado y adopta el clasicismo. Lo esencial de la obra casanoviana es el volumen v la expresión de simplicidad que le viene de Grecia, sobre todo, el período arcaico y la leve sonrisa que caracterizará, casi siempre, toda su obra, procedente de la estatuaria pre-clásica. Según Plá, la escultura de Casanovas, clásica o clasicizante, "produce una impresión de terminación de camino, de reposo exquisito, de majestuosa imperturbabilidad, de cosa que afecta pura y simplemente a la inteligencia. Es como el espectáculo superior. Debe ser la impresión que se aproxima más a aquello que significaba la ataraxía de los pirrónicos $"{ }^{8}$ Casanovas supo con su arte escultórico convertir a la mujer en arquetipo celevando la anécdota a categoria". Sus castos desnudos, sus cabezas femeninas han iluminado el arte catalán de aquella época de serenidad, de aplomo y de un inimitable sentido sublime y ascético.

Esteve Monegal llegó al clasicismo a través de las orientaciones de Clará. El suyo no fue, sin embargo, un clasicismo robusto $o$ arcaizante -como en Clará o Casanovas respectivamente- sino delicado y muy euritmico.

Si bien hay que considerar a Pau Gargallo como un escultor dentro de un cubismo vanguardista, nunca abandonó totalmente una línea tradicional dentro de un "Noucentisme" de torsos desnudos y bañistas. Josep Llorens Artigas escribe al referirse a sus desnudos: «Hay en estos desnudos una sensualidad formidable que no nace de una excitación de los sentidos, sino de la vitalidad profunda y plena que contienen, transformada en cualidades plásticas "9. Su obra noucentista es de una acusada resonancia clasicista de gran fuerza plástica, volúmeres bien definidos y fuerte expresión sensual.

Junto con Pau Gargallo, es Manolo Hugué, otro escultor independiente pero en el que el "mediterranismo" incidió en una etapa de su pro-

E. D'ORS: Glosari 1906-1910. Obra Catalana Completa. Barcelona. Ed. Selecta, 1950, págs. 949-950.

${ }^{8}$ J. PLA: “Enric Casanovas". Barcelona. Vell i Nou. Mayo de 1920, pág. 40.

9 J. LloRens ARtigas: “El desnú en l'escultura d'en Pau Gargallo". Barcelona. Rev. La má trençada, 24-12-1924, pág. 55. 
ducción escultórica aunque luego derivaría hacia una cierta plástica cubista. Manolo Hugué, llamado para el arte "Manolo", halló la raiz de su tierra, no sólo en la Venus mediterránea maillolesca, de la que da también a menudo su personal visión, sino especialmente en la plasmación de tipos rurales o pintorescos, toreros, manolas, vistos por su espontánea ironia de catalán escéptico y vital, traducida plásticamente a pequeñas figuras y relieves de robustos y rudos volúmenes. Manolo Hugué es el autor de esas mujeres macizas que muestran los volúmenes de las piernas exuberantes, a través de las faldillas a punto de reventar, agachadas, atándose la alpargata. Escribe Benet: "Terracotas, bronces, piedras duras o blandas de Hugué, desde este instante en las vitrinas de un museo imaginario, no lejos todavia de los fragmentos sumerianos de piedra negra, próximo a las esculturas de los tiempos de las pirámides, vecino de los ejemplares de arte griego de los siglos $v 1$ y $\vee$, cercano a las cabezas de Despiau y a algunos torsos de Aristides Maillol»" ${ }^{10}$. Y Folch i Torres insiste en la "Coincidencia espiritual de sus obras con ciertos pequeños bronces alejandrinos " ${ }^{11}$. En definitiva, su escultura es una amalgama personal de realismo y aspiración clásica.

La unión del prestigio de la estatuaria griega como una corporeidad del "canon" -palabra mágica del "Noucentisme"-, un neohelenismo romanizado y el ejemplo del gran precursor Arístides Maillol provocan la prolongación del "Noucentisme" escultórico en las obras de escultores como Marés y Monjó, pero, sobre todo, en el terceto de escultores compuesto por Rebull, Fenosa y Viladomat.

Tal vez el escultor más plenamente identificable con el "Noucentisme" escultórico tardio es Joan Rebull. El conocimiento de unas obras de Casanovas encaminó su visión estética. En Rebull se unen la serenidad de la belleza pura y un cierto lirismo expresivo contenido. Una escultura, la suya, rica de un agudo sentido estructural, cuyos volúmenes se ordenan lógicamente en el espacio. Escultura en el silencio ${ }^{12}$, ha llamado Carlos Riba a la de Rebull. Este "silencio" de la escultura de Rebull ha hecho pensar en un concepto egipcio de la escultura: ese silencio eterno de la estatuaria egipcia en la vida de ultratumba. Puede considerarse a Rebull como la máxima figura de la escultura catalana de la generación postnoucentista. Representó una voluntad de rigor, de clasicismo, de retorno a los orígenes y hasta incluso de integridad civica, mucho más apasionado aún que la de los primeros escultores noucentistas.

10 R. Bennet: "El gran Manolo". Barcelona. Rev. Art, $\mathrm{n}^{\circ}$ 2, noviembre 1933, págs. 33-36.

J. FOLCH I TORRES (con el seudónimo de "FLAMA»): "Escultures i dibuixos de M. Hugué». Barcelona. La Veu de Catalunya, 10-12-1917.

226. 
Apelles Fenosa estudió con Enric Casanovas, cuyo clasicismo en espíritu le marcó para toda su carrera escultórica. Su arte descubre un mundo poblado de criaturas femeninas que conservan frescas las improntas de los dedos del artista y son hijas de la tierra de la cual emergen. Su obra noucentista, por regla general en bronce oscuro, comprende figuras y grupos femeninos, de medidas reducidas, tratadas con solidez y ligereza a la vez y con un simbolismo muy mediterráneo ("Les Germanes de Faetó", "Les Quatre Estacions", "L'Aurora», «Polifem», «Font del Tres Regnes", etc.). La cualidad de fragancia y el delicado componente de la ternura son característicos de la escultura de Apelles Fenosa. Un lirismo transforma las figuras de este escultor en sutil música, hechizada y transfigurada en sus imágenes escultóricas. Sus "gracias" femeninas de tórax finos y delgados y caderas amplias, y la cadencia amable de los cabellos de sus figuras, prodigan, en giros armoniosos, la admirable identificación de gracilidad que caracteriza a nuestro escultor. En la obra de Fenosa hay ritmos ágiles, actualidad de vuelo y de reposo, todo ello aglutinado de lirismo que impone a las figuras la gracia inerme de su candor suavisimo.

Josep Viladomat destacó como la práctica totalidad de los escultores noucentistas, por la estupenda colección de desnudos femeninos que irá realizando a lo largo de su carrera. En ellos sobresale ese respeto a la forma humana, tomando del clasicismo griego y del Renacimiento italiano, una sensual complacencia en la descripción del cuerpo humano y la voluntad de transcribir la palpitación de la carne viva, joven y firme. El estilo escuitórico de Viladomat es hijo del mediterranismo propio de los escultores de la generación noucentista en Cataluña, si bien atenuado a veces con un cierto realismo de raiz donatelliana. 


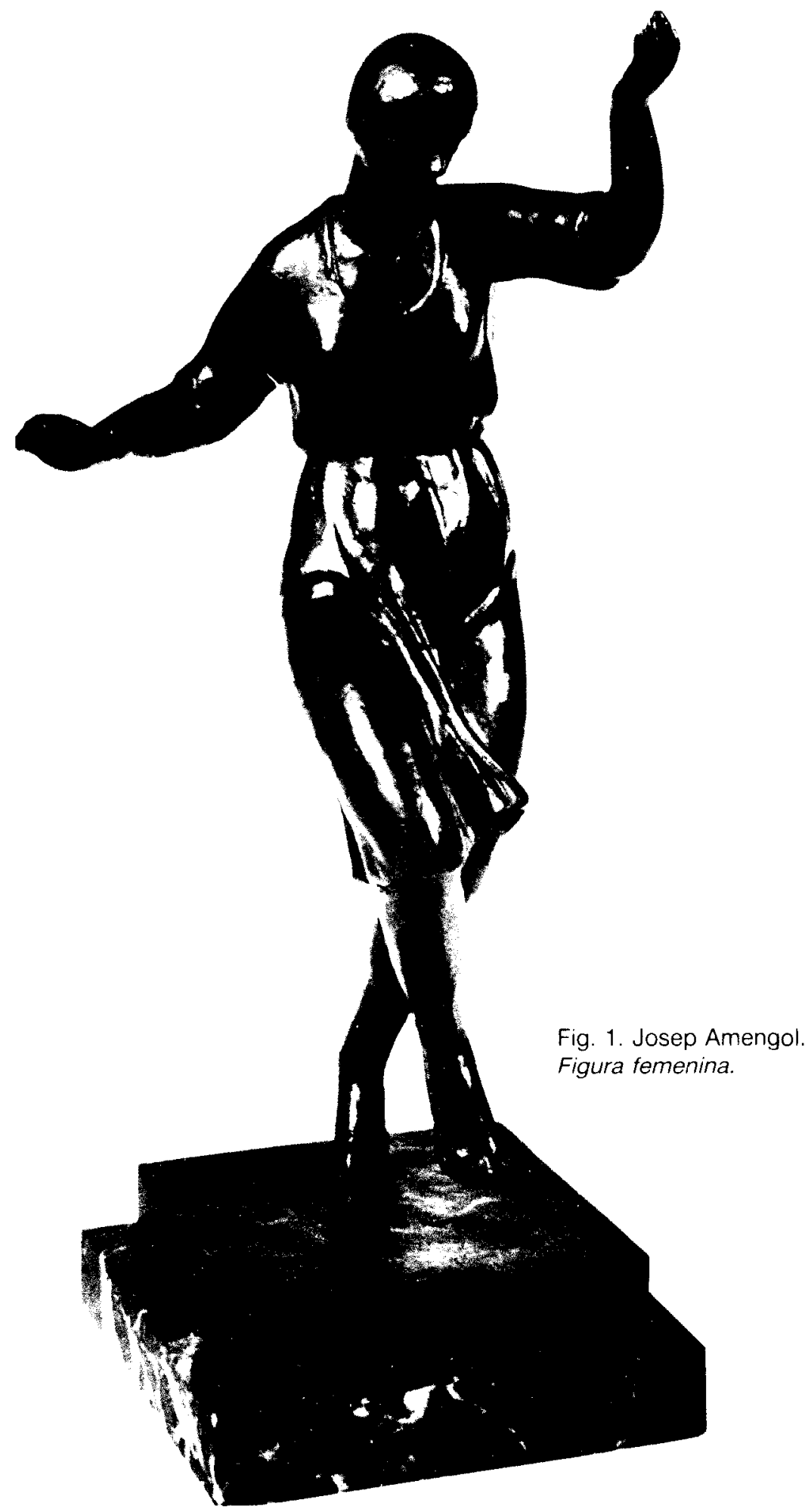


"Cuando MAILLOL realizó, en 1900, una mujer sentada, robusta, reposada y perfecta, tituló significativamente a aquel desnudo Mediterránea. Con ella había esculpido no sólo la que tal vez sea su mejor obra, sino indiscutiblemente el programa estético de la escultura catalana noucentista. Constituye un extraordinario ejemplo de formas cacizas, superficie lisa y contorno continuo, expresión de los volúmenes esenciales. El volumen de cada detalle plástico recuerda una forma geométrica: asi, los senos parecen conos redondeados, y brazos y piernas, cilindros de diámetro variable. Armonia y equilibrio estáticos presiden una esencialidad inerte de tradición griega.»

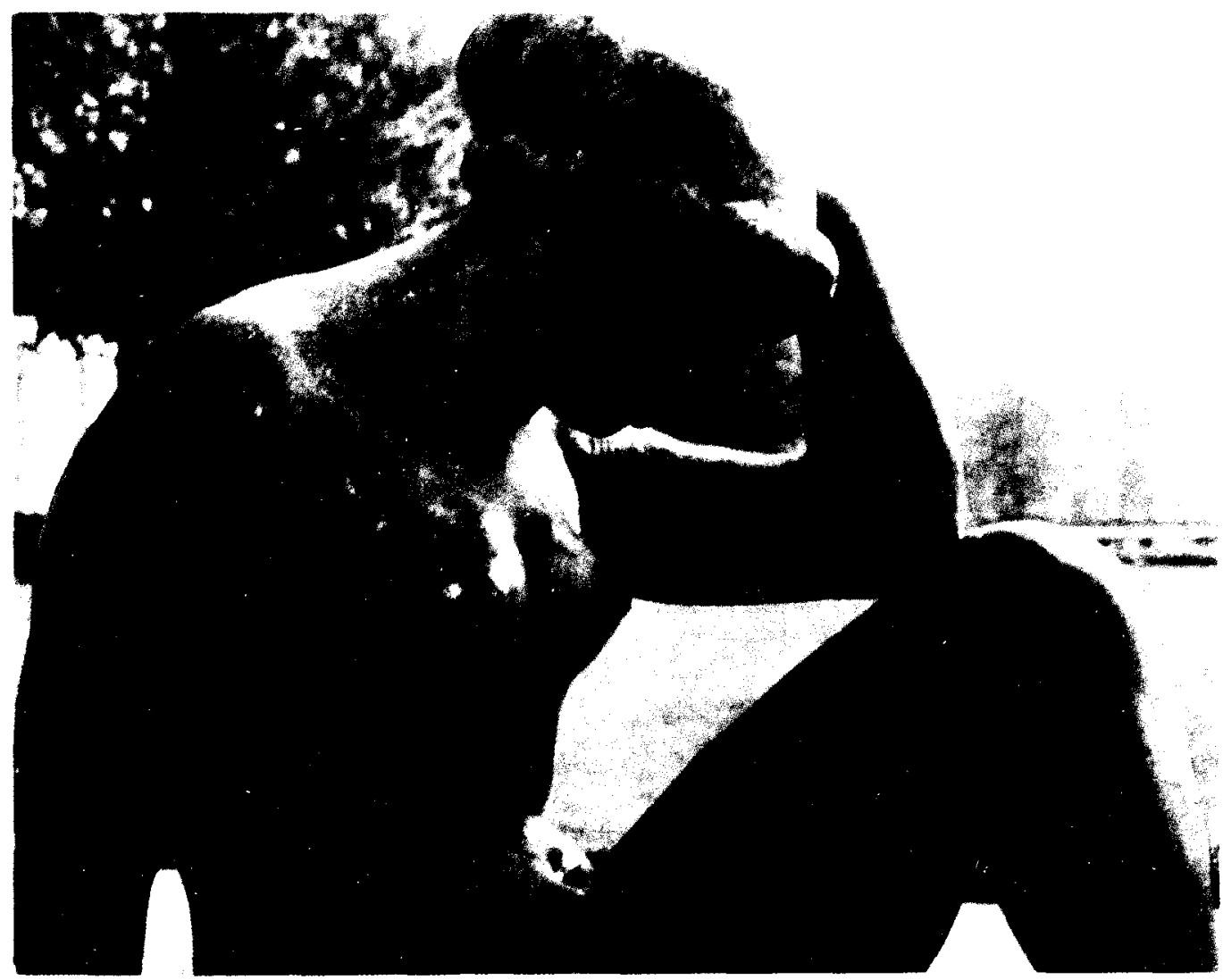

Fig. 4. Aristides Maillol. Mediterránea. 
"Aristides MAILLOL y Josep CLARÁ triunfan con sus admirables desnudos de "diosas" que alzan sus formas triunfantes bajo el sol mediterráneo, a la orilla del mar azul, en las ágoras o en los jardines."

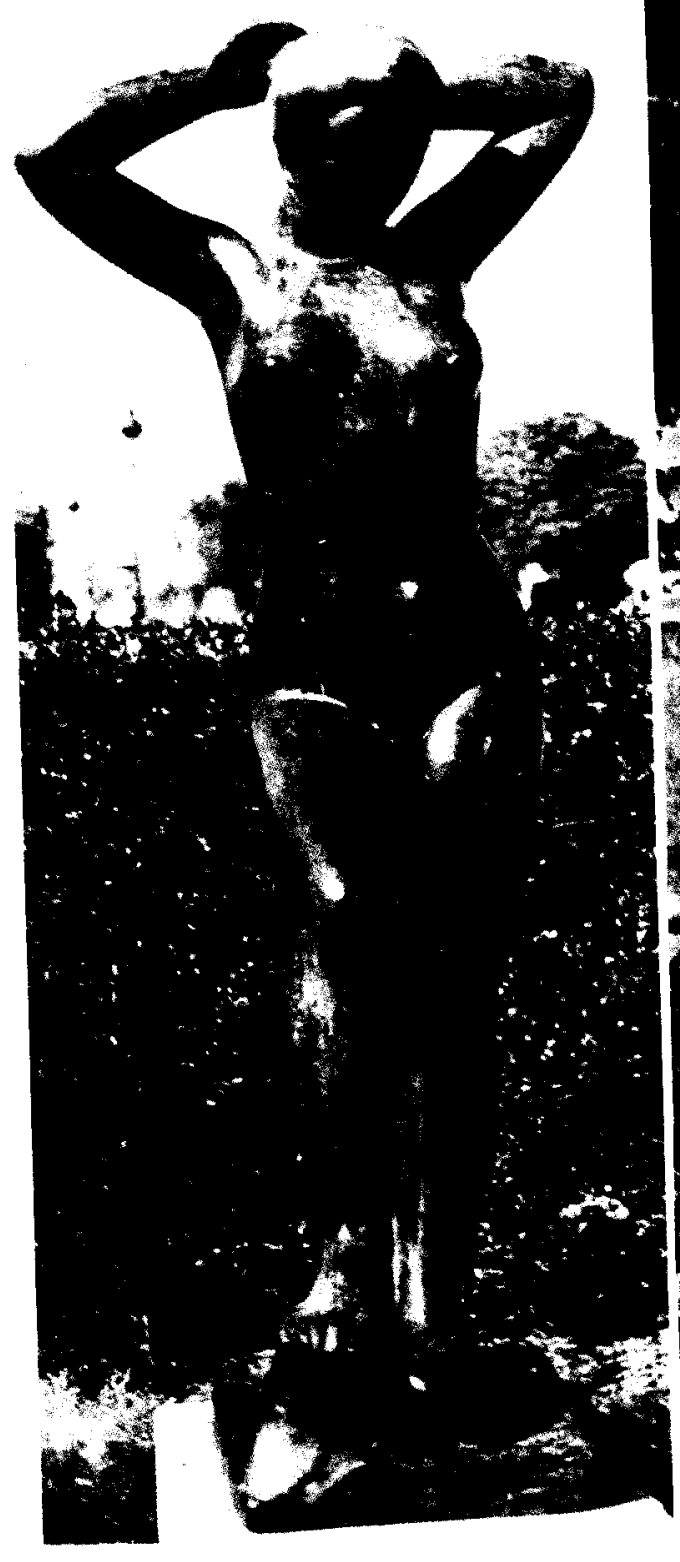

Fig. 5. Aristides Maillol. Bañista con los brazos levantados.

Paris. Jardin de las Tullerias.

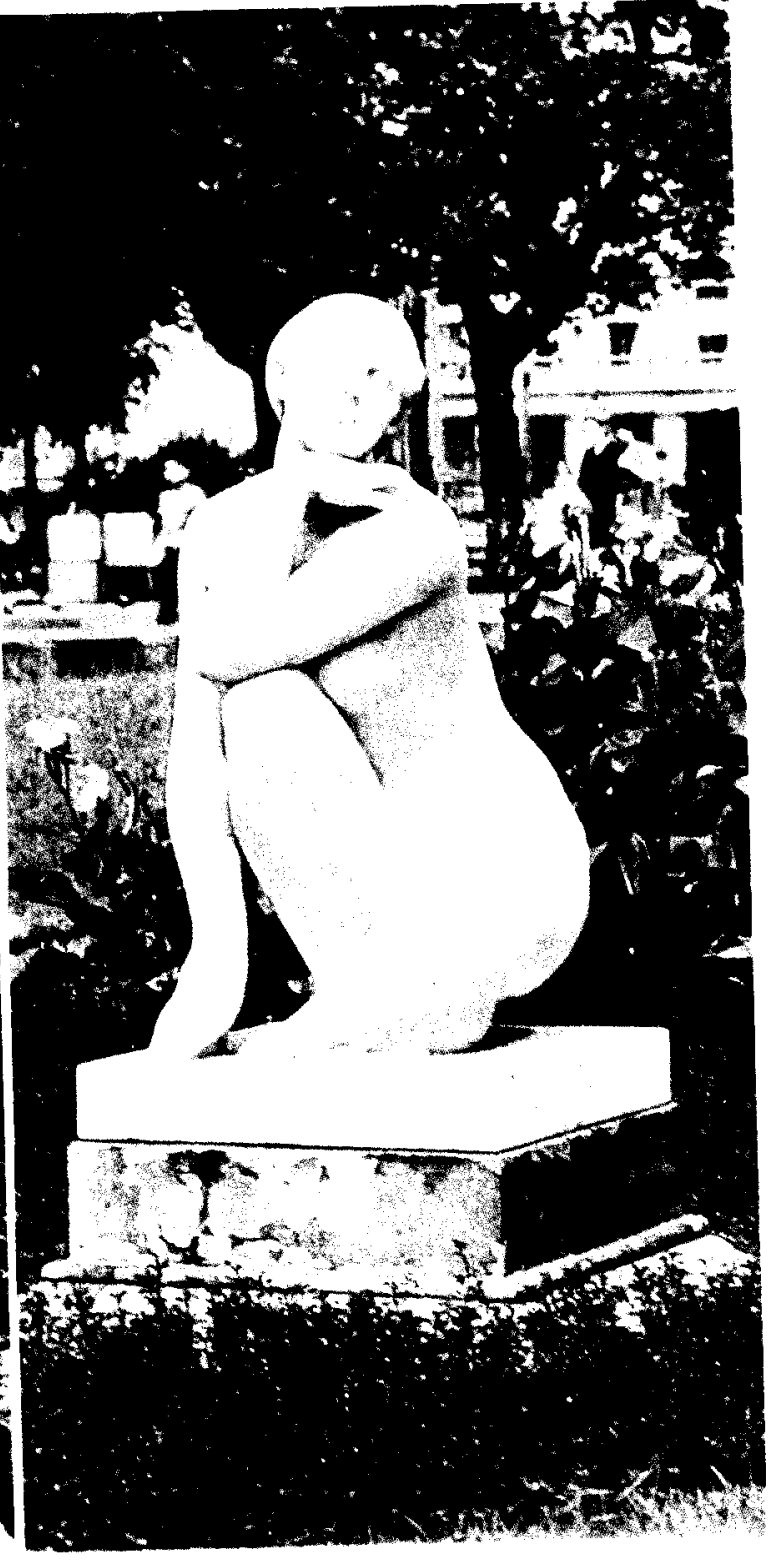

Fig. 6. Josep Clará. Diosa. Barcelona. Plaza de Cataluña. 
"Manolo HUGUÉ, "Manolo" es el creador de tipos y mujeres rurales o pintorescas, como esta "manola», de formas robustas y macizas y de volúmenes exhuberantes que se emparentan con los antiguos bronces alejandrinos."
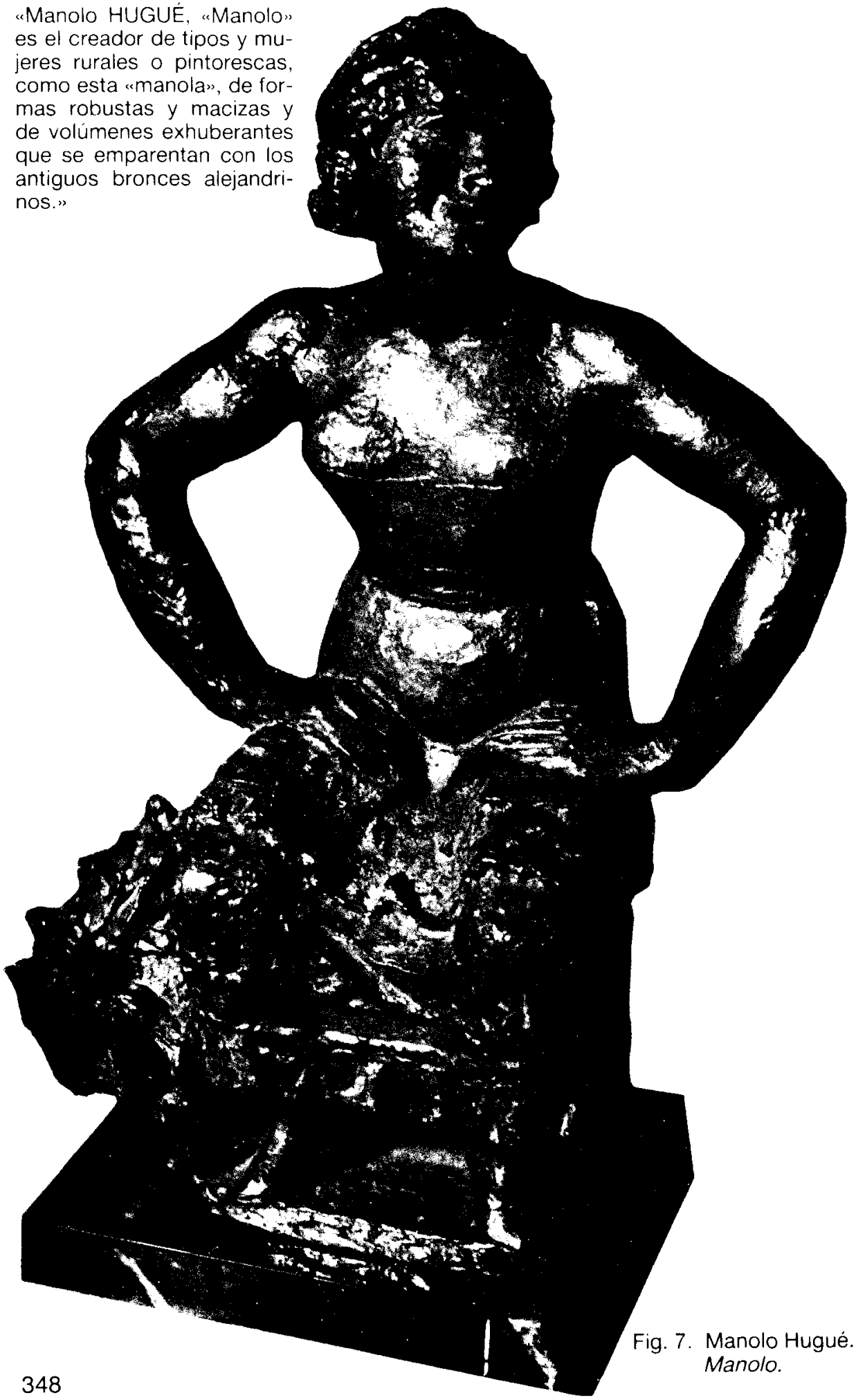

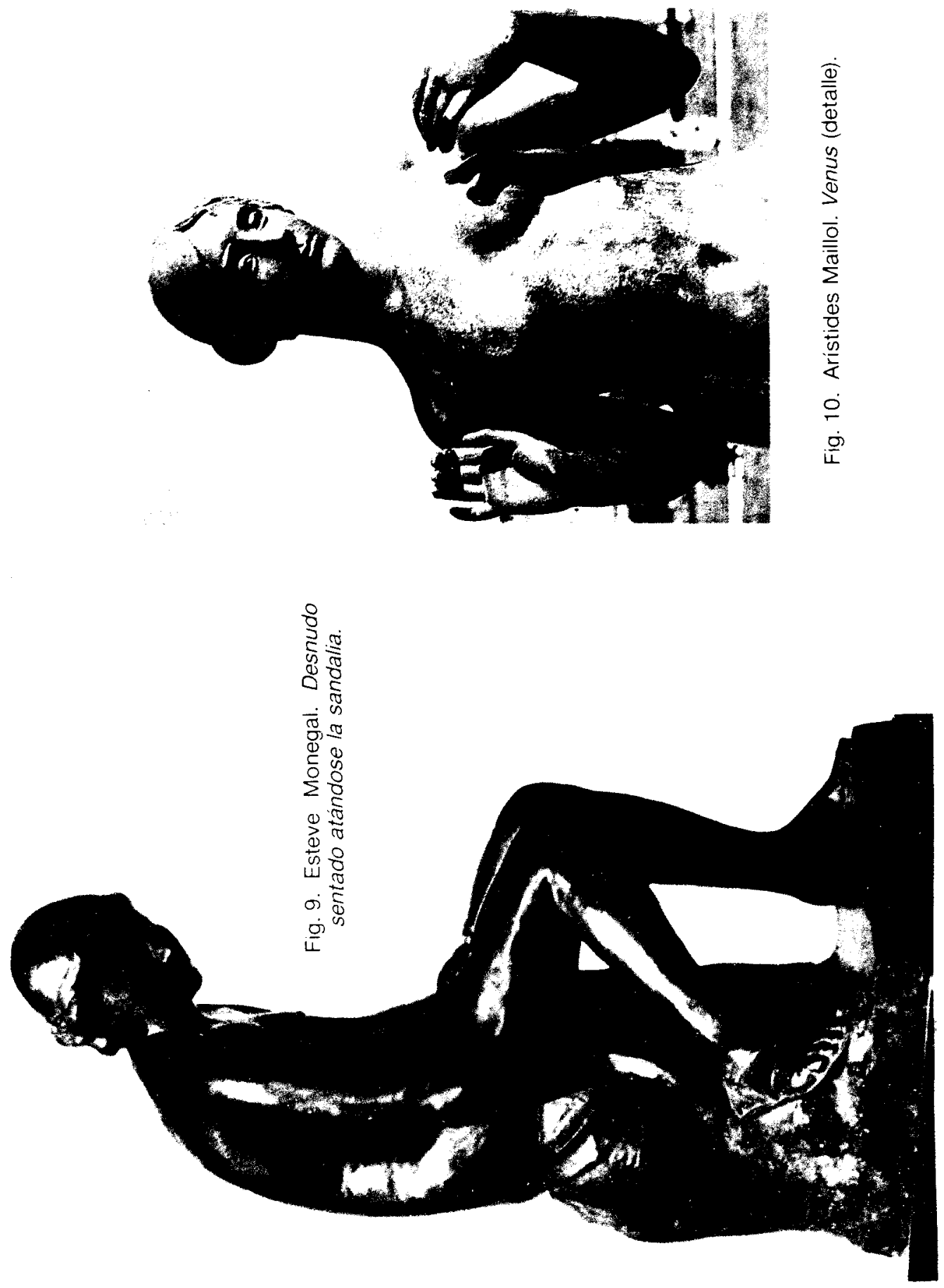
"La escultura de CASANOVAS produce una impresion de terminación de camino, de reposo exquisito, de majestuosa imperturbabilidad, de cosa que afecta pura y simplemente a la inteligencia. Es como un espectáculo superior. CASANOVA supo convertir su arte escultórico en arquetípico, elevando "la anécdota a categoria". Sus sobrias cabezas han iluminado el arte catalán de aquella época de serenidad, de aplomo y de un inimitable sentido sublime y ascético."
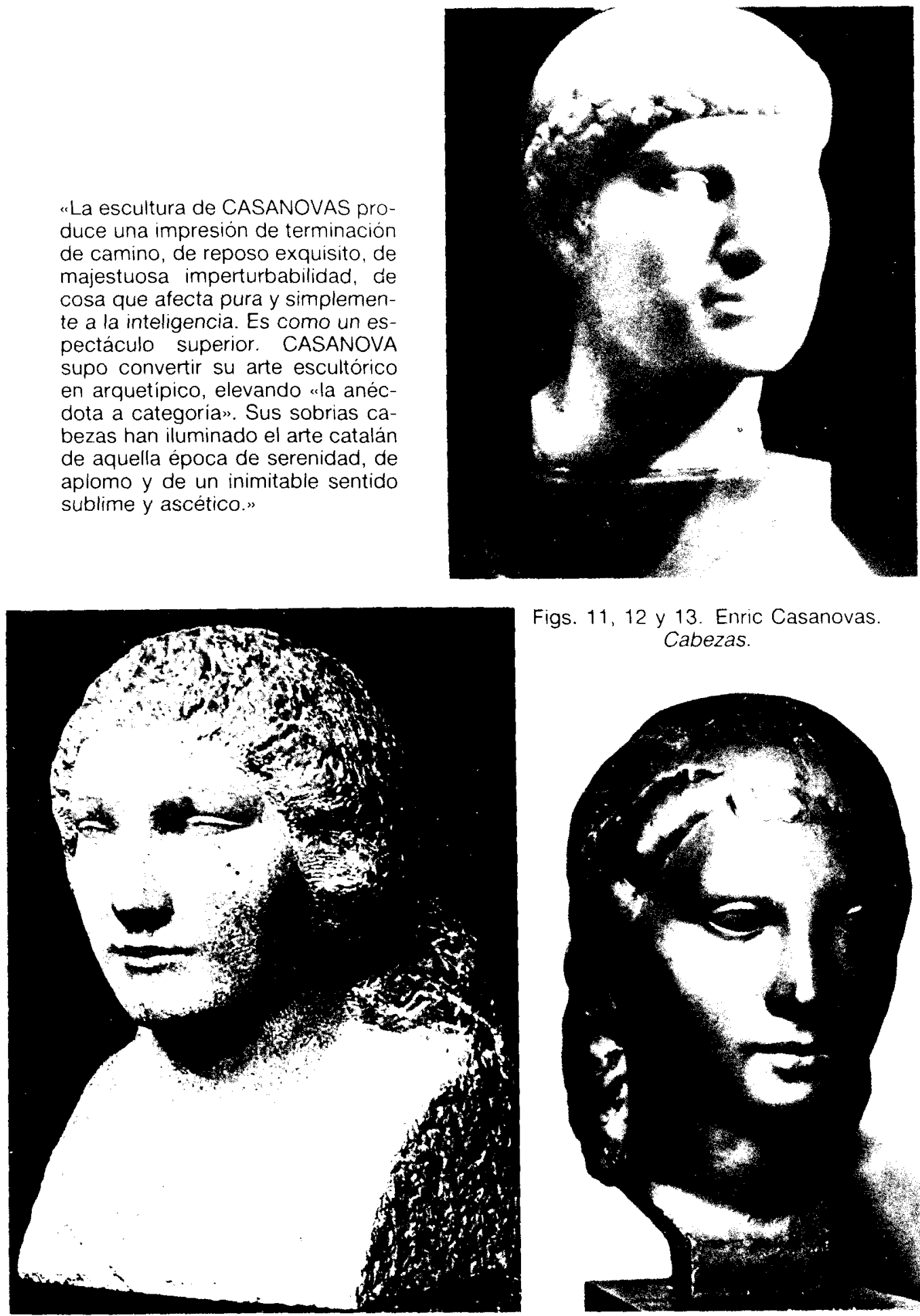

Figs. 11, 12 y 13. Enric Casanovas. Cabezas.

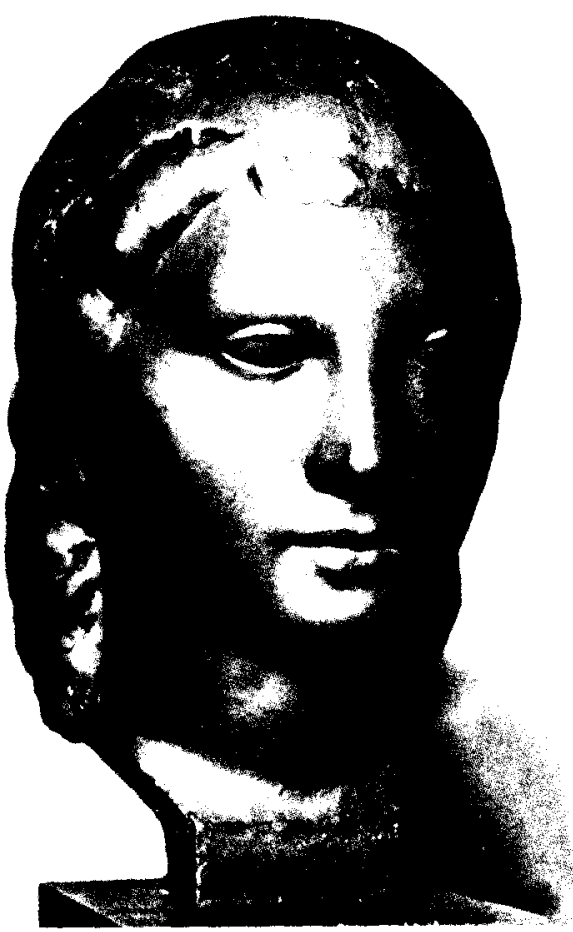


Fig. 14. Haydée de Telur. Busto de E. D'Ors.

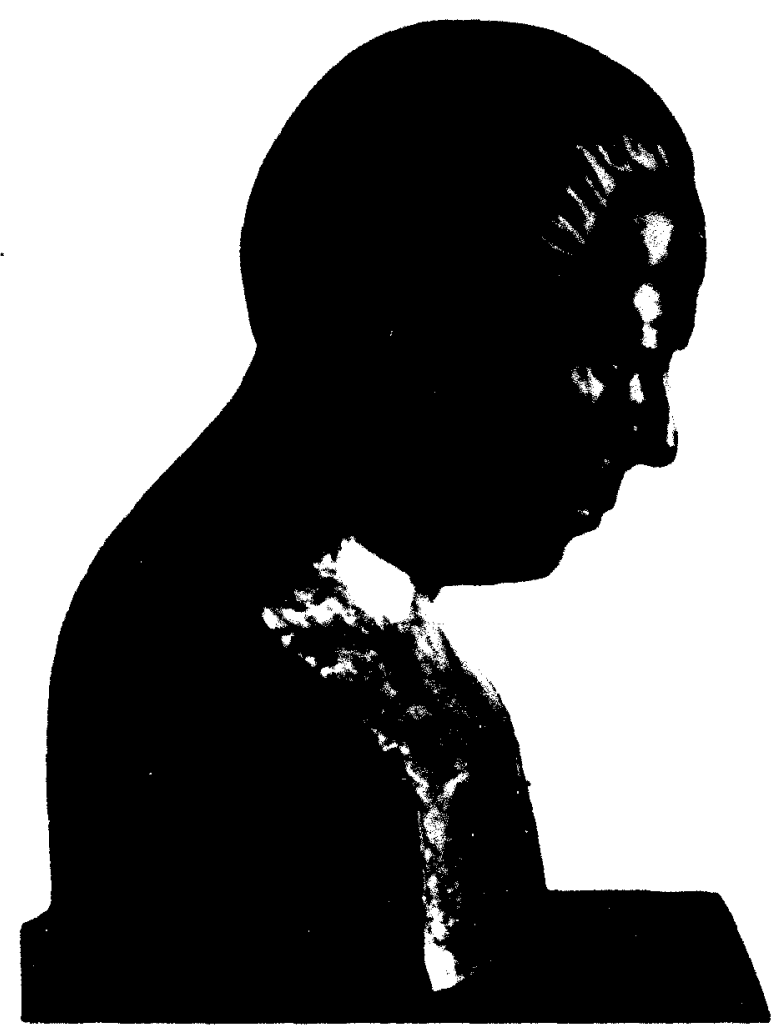

"El símbolo de la renovación estético-filosófica del Noucentismo en la novela $L a$ Ben Plantada de Eugenio D'ORS. La figura helénica de Teresa, la Ben Plantada, constituye la mejor versión plástico-literaria del Noucentisme, una especie de símbolo en forma de estatua. Con su sentido del orden, de la serenidad y del clasicismo simboliza no sólo a Cataluña, sino todo el espíritu mediterráneo.

El Noucentisme es identificable sobre todo en la escultura y La Ben Plantada es, desde luego, antes que nada una estatua.» 

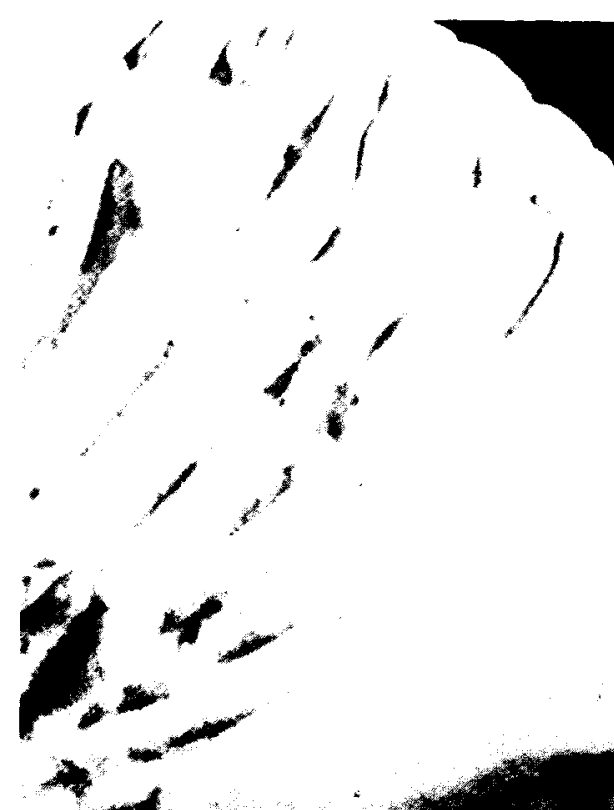


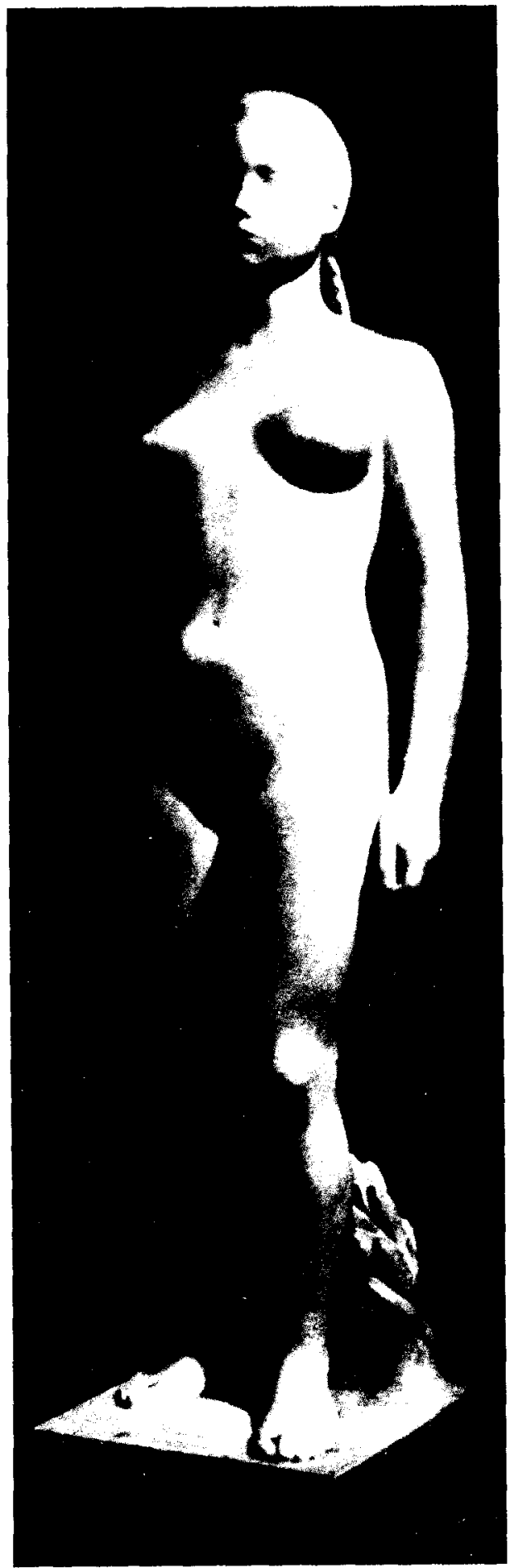

"Una de las notas más significativas de la escultura noucentista es el predominio casi absoluto del desnud femenino como tema. La práctica totalidad de los grandes escultores noucentistas, desde MAILLOT a REBULL, desde CLARÁ a VILADOMAT, cultivaron básicamente el modelado sincero y directo del cuerpo desnudo de la mujer mediterránea casi como única fuente de inspiración. Consideran el desnudo femenino como el tema omnipotente que les permite conquistar las armonias de volumen y superficie más perfectas».

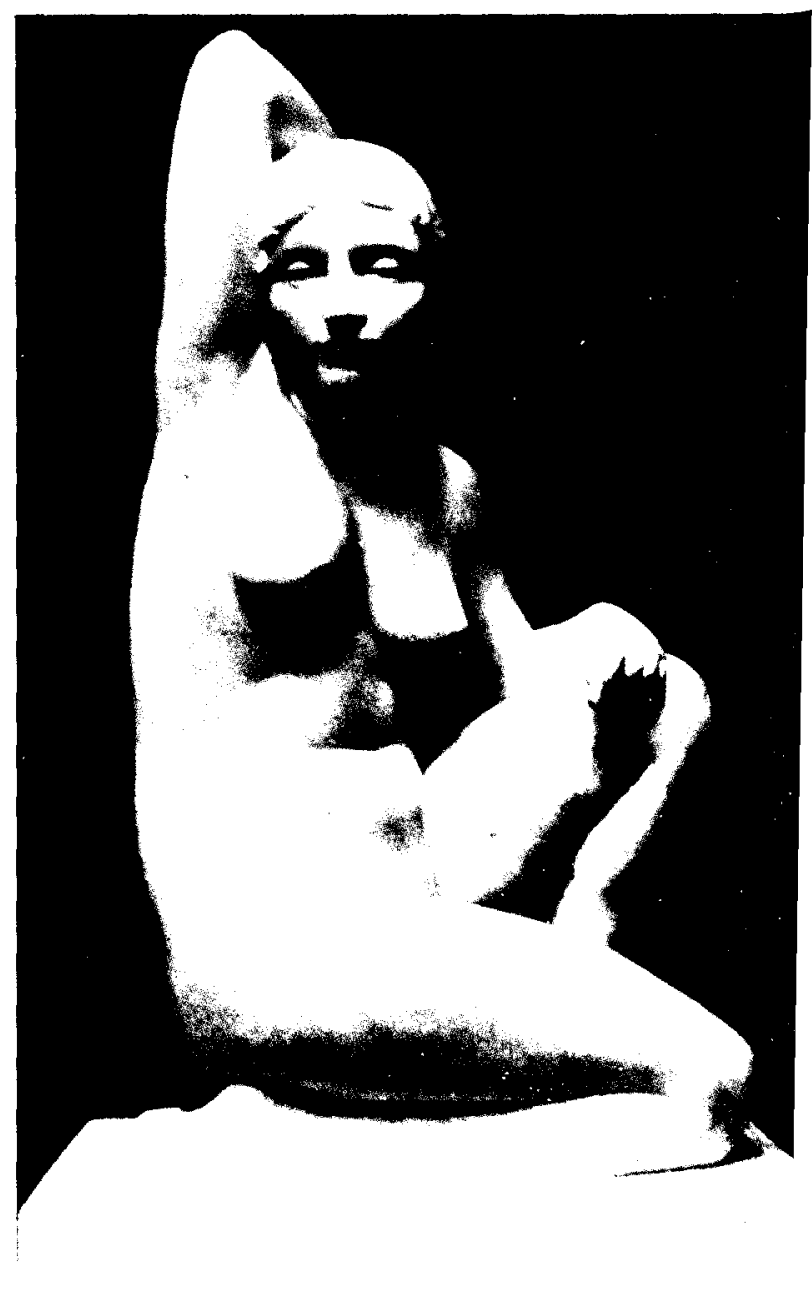

Fig. 17. Liorenç Cairó. Desnudo de pie.

Fig. 16. Josep Dunyac. Desnudo sentado. 